\title{
PEMBUATAN DAN PENGGUNAAN ALAT PERAGA BAGI ANAK BERKEBUTUHAN KHUSUS
}

\author{
Lily Eka Sari \\ Fakultas Keguruan dan Ilmu Pendidikan, Program Studi Pendidikan Guru Sekolah Dasar \\ Universitas Kristen Petra \\ Jl. Siwalankerto 121-131, Surabaya 60236 \\ Email: lilyesari@petra.ac.id
}

\begin{abstract}
Abstrak: Di Indonesia, jumlah anak berkebutuhan khusus yang berusia sekolah terus meningkat. Sekolah dan orang tua murid perlu berkolaborasi untuk mendukung proses belajar siswa. Dalam hal ini, perlu ada pengadaan dan penggunaan alat peraga bagi siswa berkebutuhan khusus. Tulisan ini bertujuan untuk mengkaji manfaat pembuatan dan penggunaan alat peraga bagi anak berkebutuhan khusus. Pembuatan dan penggunaan alat peraga ditujukan terutama bagi siswa berkebutuhan khusus di tingkat Sekolah Dasar, di sekitar Sekolah Teologi Kristen Pelangi Kristus, Surabaya. Dalam kegiatan tersebut, digunakan metode direct teaching dan praktik agar setiap peserta bisa menyesuaikan alat peraga dengan kebutuhan siswa. Hasil pelatihan yang telah dilakukan di Sekolah Teologi Kristen Pelangi Kristus, Surabaya menunjukkan bahwa siswa mampu menangkap materi pembelajaran jika diadakan adaptasi dan modifikasi cara menyampaikan materi.
\end{abstract}

Kata Kunci: Anak berkebutuhan khusus, alat peraga, metode mengajar

\begin{abstract}
The prevalence of students with special needs in Indonesia keeps growing. Schools and parents need to collaborate in order to support the students' learning processes. In this case, it is necessary to create and use teaching manipulatives for students with special needs. This paper was written to analyze the benefits of creating and using teaching manipulatives for students with special needs. The product materials were designed for students with special needs in Elementary School level, in the areas around Sekolah Teologi Kristen Pelangi Kristus, Surabaya. Throughout the activities, direct teaching and hands-on methods were used. Therefore, each participant might tailor the product to the needs of each child. The results show that the students were able to comprehend the teaching contents more easily when there were adaptations and modifications made to deliver those contents.
\end{abstract}

Keywords: Students with special needs, teaching manipulatives, teaching methods

\section{PENDAHULUAN}

Akhir-akhir ini ditengarai semakin banyak anak yang tidak bisa berprestasi maksimal dengan pola belajar persekolahan yang hanya menerapkan proses serta cara-cara pendidikan yang sifatnya konvensional. Para guru dan orangtua murid membutuhkan ketrampilan untuk dapat melakukan pendekatan yang berbeda, sehingga dapat secara maksimal melayani anak-anak yang memiliki kecenderungan dengan kebutuhan pendekatan dan pendampingan belajar yang unik dan khusus.

Centers for Disease Control and Prevention (CDC) dalam penelitiannya melaporkan bahwa di tahun 1997 sampai dengan 2008 terjadi 17,1\% kenaikan jumlah anak yang didiagnosa dengan Developmental Disabilities (2015). Di Indonesia, persentase jumlah anak berkebutuhan khusus dalam interval kurun waktu 3 (tiga) tahun juga menunjukkan peningkatan. Kementerian Kesehatan RI (2014) dan Pusat Data dan Informasi Kementerian Kesehatan RI (2014) melaporkan paparan dan pemetaan disabilitas di Indonesia. Disabilitas dalam hal ini tidak hanya mempengaruhi populasi penduduk dewasa, melainkan juga anak-anak.

Sekolah Teologi Kristen Pelangi Kristus hadir untuk melayani para murid, orangtua, maupun orangorang yang tinggal di sekitar kampus. Di sekitar kampus Sekolah Teologi Kristen Pelangi Kristus terdapat beberapa lokasi kawasan tempat tinggal. Para penduduk di sekitar kampus terdiri dari beragam strata sosial, berbagai macam etnik, dengan latar belakang agama dan kepercayaan masyarakat yang berbeda-beda namun dapat hidup dalam kebersamaan dan merupakan masyarakat yang dapat hidup berdampingan dengan cukup toleran. 
Pelayanan yang diberikan bukan hanya berupa layanan pendidikan Kristiani yang formal, tetapi juga pelayanan kesehatan, pemberantasan buta aksara lewat program Taman Bacaan, dan sebagainya. Sejak 2007, Sekolah Teologi Kristen Pelangi Kristus pada setiap akhir minggu, pada hari tertentu dan jam tertentu telah menerapkan program pelayanan pengabdian pada masyarakat sekitar sekolah dengan fokus utama melayani anak-anak yang dari keluarga masyarakat yang dengan latar belakang ekonomi lemah di lokasi sekitar sekolah dengan usia dari 4 tahun hingga 12 tahun.

Sering terjadi diskusi dengan beberapa orang tua yang mengantar anak-anak mereka mengikuti yang dilaksanakan oleh murid-murid SMP dan Sekolah Menengah Atas. Kebanyakan diskusi yang muncul adalah adanya kesulitan para orang tua murid dan pendidik Sekolah Teologi Kristen Pelangi Kristus dalam menyampaikan materi. Dalam hal ini ada beberapa masalah yang timbul, antara lain: 1) Apa saja tipe kebutuhan khusus para siswa, sehingga mereka kesulitan mengikuti pelajaran dengan metode mengajar yang konvensional? 2) Apa yang dibutuhkan para siswa agar dapat memahami materi pelajaran? 3) Apa saja intervensi yang bisa diberikan oleh para pendidik maupun orangtua, agar siswa bisa memahami materi dengan lebih mudah? Dengan adanya kebutuhan dan masalah tersebut, diajukanlah hibah untuk melaksanakan pengabdian kepada masyarakat, agar para orangtua murid bisa mendapatkan informasi dan pelatihan yang bisa digunakan dalam masing-masing keluarga.

\section{KAJIAN PUSTAKA}

Menurut Kamus Besar Bahasa Indonesia, disabilitas berarti (1) keadaan (seperti sakit atau cedera) yang merusak atau membatasi kemampuan mental dan fisik seseorang (2) keadaan tidak mampu melakukan hal-hal dengan cara yang biasa.

Jumlah anak-anak dengan kondisi khusus ini ditemukan jumlahnya semakin cukup banyak. Peningkatan jumlah anak berkebutuhan khusus di keluarga yang berlatarbelakang ekonomi lemah ternyata terjadi secara global. Boat \& Wu (2015) mencatat bahwa di Amerika Serikat, jumlah anak berkebutuhan khusus dari keluarga yang menerima santunan finansial meningkat dari $0.74 \%$ di tahun 2004 menjadi $0.89 \%$ di tahun 2013.

Di Indonesia, ditengarai ada peningkatan jumlah populasi anak berkebutuhan khusus. Hal ini dapat dilihat dalam Tabel 1 dan Tabel 2.

\section{METODE PELAKSANAAN}

Mengingat angka prevalensi anak berkebutuhan khusus yang semakin tinggi, perlu diadakan intervensi dini. Penyuluhan dan pembinaan akan diberikan kepada para guru dan orangtua anak berkebutuhan khusus. Hal ini akan dilaksanakan dalam waktu yang sama, agar baik guru maupun orangtua anak bisa mendapatkan pengertian yang sama pada saat menangani kebutuhan anak.

Persentase penduduk penyandang disabilitas dapat dilihat dalam Tabel 1, yang merangkum data Badan Pusat Statistik di Indonesia.

Tabel 1. Persentase Penduduk Penyandang Disabilitas Berdasarkan Data Susenas Tahun 2003, 2006, 2009, 2012

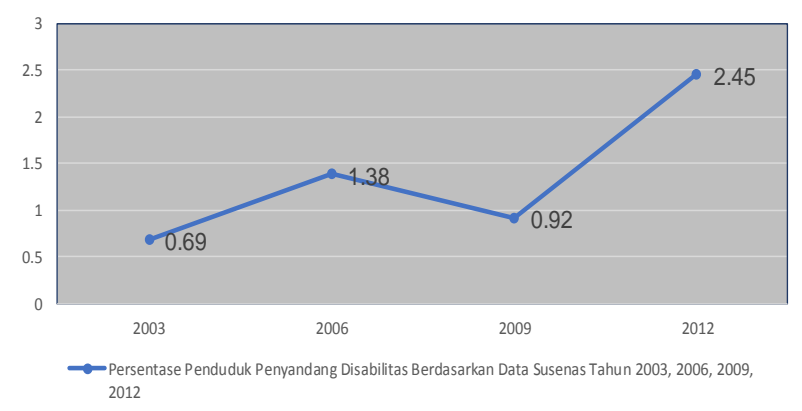

Sumber: BPS

Badan Pusat Statistik di Indonesia meneliti lebih lanjut jenis disabilitas yang disandang oleh sampel data yang diambil. Distribusi dan jenisnya dapat dilihat pada Tabel 2.

Tabel 2. Distribusi penyandang Disabilitas menurut Jenis Disabilitas berdasarkan Data Susenas tahun 2012

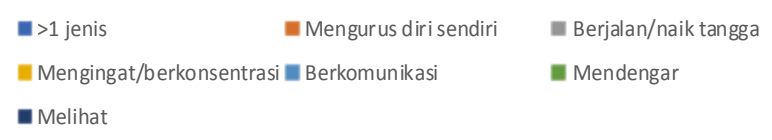

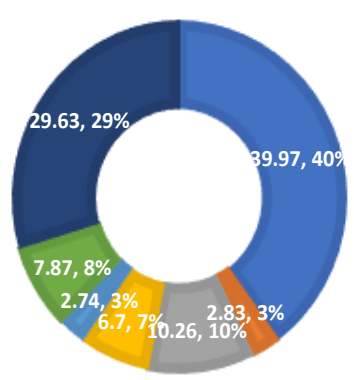

Sumber: BPS

Menurut Individuals with Disabilities Act (2004), Learning Disability mencakup kesulitan dalam satu atau lebih proses psikologis yang dibutuhkan untuk mengolah bahasa, baik lisan maupun tertulis. Proses tersebut sangat dibutuhkan untuk kemampuan mendengarkan, berpikir, berbicara, membaca, dan menulis.

Siswa berkebutuhan khusus perlu diberi motivasi ekstra agar mereka mau berusaha. Para siswa tersebut akan lebih merasa termotivasi dan terpacu jika ada keinginan untuk memecahkan masalah, 
yang timbul dari diri mereka sendiri (Kaldenberg, et. al, 2014). Karena itu, para guru dan orangtua perlu menyajikan materi dengan cara yang lebih menarik. Dalam hal ini, pembelajaran bisa memakai model problem-based learning (Kaldenberg, et. al, 2014).

Siswa yang menyandang kebutuhan khusus sangat memerlukan representasi visual atau wujud konkret materi yang sedang dipelajari (Kaldenberg, et. al, 2014). Mereka sering mengalami kesulitan menangkap konsep yang baru, apalagi jika konsep itu berwujud abstrak. Oleh sebab itu, guru dan orang tua perlu membantu mereka memetakan konsep dan alur pokok pikiran dalam bentuk yang mudah dilihat dan dipegang oleh siswa.

\section{SASARAN KEGIATAN PENGABDIAN MASYARAKAT}

Pengabdian kepada masyarakat dalam kesempatan ini diadakan di Program Taman Bacaan Sekolah Teologia Kristen Pelangi Kristus. Kampus Sekolah Teologia Kristen Pelangi Kristus menjadi lokasi utama kegiatan ini. Pihak Sekolah menyediakan tempat dan beberapa orang guru yang terlibat dalam kegiatan ini.

Di akhir kegiatan ini diharapkan ada luaran dalam bentuk:

- Modul yang dapat dipakai secara mandiri oleh para guru maupun orang tua anak berkebutuhan khusus

- Alat peraga yang bisa dibuat dan digunakan sendiri oleh para guru maupun orang tua anak berkebutuhan khusus

- Mini Lab di kampus Sekolah Teologia Kristen Pelangi Kristus, yang bisa dijadikan pilot project untuk melayani anak-anak berkebutuhan khusus

\section{HASIL DAN PEMBAHASAN}

\section{Tipe Kebutuhan Khusus Siswa Taman Bacaan}

Pada hari Jumat, 27 Januari 2017, dilakukan Analisa Kondisi Lingkungan. Dalam kegiatan ini diadakan pertemuan dengan para orang tua guna mendata kebutuhan khusus yang disandang anakanak di Taman Bacaan serta Sekolah Teologia Kristen Pelangi Kristus.

Melalui percakapan dengan guru dan orang tua, serta uraian ciri-ciri para siswa, dapat dilihat bahwa secara umum ada beberapa kebutuhan khusus yang dominan. Ciri-ciri menonjol yang diutarakan menunjukkan bahwa sebagian besar siswa memiliki Learning Disability (LD) atau kesulitan belajar. Sebagian besar para siswa menunjukkan indikator kuat $\mathrm{LD}$ yang terdapat di bawah ini.

\section{Kebutuhan Para Siswa}

Setelah tipe kebutuhan khusus para siswa pada umumnya bisa diidentifikasi, proses berikutnya adalah menentukan baseline kegiatan selama Program Pengabdian Kepada Masyarakat. Dalam baseline ini, setiap siswa didata, apa saja kelebihannya, apa yang sudah dikuasainya, dan apa yang dibutuhkannya. Dalam proses ini, para guru dan orang tua berlatih mengobservasi dan menyusun laporan yang bisa menggambarkan kondisi anak secara objektif.

Berdasarkan baseline pula, kegiatan selama Program Pengabdian Kepada Masyarakat disusun guna memenuhi kebutuhan para siswa.

\section{Kemampuan Membaca}

Para siswa pada umumnya sudah bersekolah di jenjang Sekolah Dasar. Bahkan ada yang secara biologis sudah memasuki usia yang cukup untuk mengenyam pendidikan di Sekolah Menengah Pertama. Akan tetapi, para siswa tidak menunjukkan kemampuan membaca yang setara dengan kelompok jenjang kelas maupun kelompok usia.

Ada berbagai faktor yang menyebabkan timbulnya kesulitan para siswa tersebut. Faktor pola asuh bisa menyebabkan kesulitan dalam hal ini. Faktor berikutnya adalah kesulitan belajar atau Learning Disability yang memang disandang oleh anak.

Faktor pertama adalah pola asuh. Para orang tua perlu membiasakan anak untuk membaca sejak usia dini. Hal ini sangat berpengaruh pada pola pikir, empati, emosi, maupun kemampuan kognitif anak. Dengan memperkaya kosa kata, anak bisa menelaah duduk masalah secara lebih objektif. Orang tua juga perlu memberi contoh dan teladan untuk gemar membaca. Dengan melihat bahwa orang tuanya rutin meluangkan waktu untuk membaca materi yang bermutu, anak juga akan memiliki kebiasaan membaca materi yang bermutu. Di samping itu, orang tua juga perlu meluangkan waktu untuk membaca bersama dengan anak. Aktivitas membaca bersama akan menumbuhkan ikatan atau bonding antara orang tua dan anak. Pola asuh yang dijabarkan di atas bisa berdampak positif pada kemampuan anak dalam hal membaca.

Faktor berikutnya adalah Learning Disability dalam hal membaca. Pada umumnya, kesulitan mengenali huruf, bunyi huruf, apalagi isi bacaan, disebut Dyslexia. Hal ini bisa disebabkan oleh faktor keturunan maupun fisik. Siswa yang menyandang Dyslexia sulit mengikuti pelajaran di sekolah, karena pada umumnya guru masih mengandalkan buku teks dalam menyampaikan materi. Anak harus membaca teks, lalu menjawab pertanyaan seputar isi bacaan tersebut. Siswa yang memang menyandang Dyslexia akan merasa kesulitan 
menjawab pertanyaan karena memang sulit membaca teks tersebut. Di samping itu, anak bisa kehilangan rasa percaya diri jika guru tidak berhasil menyikapi perbedaan anak, hal ini bisa berdampak pada perilaku anak. Anak-anak yang seperti ini akan cenderung menunjukkan perilaku negatif sebagai kompensasi perbedaannya.

\section{Kemampuan Berbahasa}

Kemampuan berbahasa tidak terbatas pada kemampuan berbicara dalam bahasa tertentu. Pada dasarnya, kemampuan berbahasa erat hubungannya dengan ketrampilan komunikasi, kecerdasan mengelola emosi, sampai kepada kemampuan mengeksekusi instruksi.

Anak yang mengalami kesulitan mengolah instruksi karena masalah ini cenderung dianggap anak yang nakal, bahkan bodoh. Mereka butuh waktu yang lebih lama untuk mencerna sampai melaksanakan perintah. Jika terbawa sampai usia produktif, orang dengan kesulitan berbahasa bisa mengalami kesulitan sewaktu bekerja. Oleh karena itu, anak-anak seperti ini butuh belajar teknik dan adaptasi yang bisa dipakai dalam menyiasati kebutuhan mereka.

\section{Kemampuan Matematika}

Secara umum, kesulitan dalam hal matematika disebut Dyscalculia. Dari istilah tersebut, bisa ditebak bahwa penyandangnya sulit memahami konsep angka. Sebenarnya, kesulitan para penyandangnya tidak berhenti di situ saja.

Kemampuan matematika tidak terbatas pada operasional hitung saja. Di kalangan masyarakat awam, bahkan di sekolah, anak diajari simbol angka sejak usia dini. Padahal, simbol angka hanya perwakilan sebuah bilangan. Sebenarnya, ada banyak kemampuan yang dibutuhkan anak untuk bisa memahami konsep yang lebih besar.

Kemampuan dalam hal matematika mencakup konsep yang beragam. Sejak usia dini, anak perlu diajari kemampuan mengelompokkan benda berdasarkan atribut dan kronologinya. Instruksi dalam bidang ini melibatkan beberapa kosa kata penting, misalnya: besar-kecil, atas-bawah, pertamaterakhir, dan nama-nama warna. Dari situ, anak juga perlu diajari membuat perkiraan, baik dari segi volume, jarak, waktu, maupun jumlah.

Dyscalculia bisa membawa beberapa dampak negatif. Seperti halnya orang yang mengalami kesulitan apa pun, para penyandang Dalam kehidupan sehari-hari, orang yang mengalami kesulitan dalam hal kemampuan matematika bisa menunjukkan kesulitan dalam hal seperti: ketepatan waktu, menyusun anggaran, dan sebagainya. Siswa yang mengalami kesulitan mengikuti pelajaran yang berhubungan dengan olah angka maupun konsep matematika lain akan cenderung menunjukkan perilaku negatif sebagai kompensasinya.

\section{Intervensi yang Bisa Diberikan}

Berdasarkan pemetaan kebutuhan tersebut di atas, perlu ada penyuluhan dan kegiatan membuat alat peraga. Hal ini dirasa perlu untuk dapat memberikan intervensi oleh para pendidik maupun orangtua, agar siswa bisa memahami materi dengan lebih mudah. Kegiatan tersebut mencakup materi yang bersifat akademik (berhitung, membaca, identifikasi warna, dsb), dan ketrampilan sosial.

Dalam kegiatan ini, orang tua dan guru bersama-sama membuat beberapa jenis alat peraga. Alat peraga yang dibuat mencakup File Folder Games $^{\mathrm{TM}}$, Sentence Strips dan Social Story ${ }^{\mathrm{TM}}$. Alat peraga di atas dipilih untuk digunakan dalam pelatihan ini dengan pertimbangan sebagai berikut:

1) Alat peraga dapat digunakan untuk materi mata pelajaran yang sangat beragam, atau tidak terbatas;

2) Bahan yang dibutuhkan harganya terjangkau;

3) Bahan yang dibutuhkan mudah didapat di toko atau gerai dekat rumah;

4) Cara membuatnya tidak sulit;

5) Proses pembuatannya bisa melibatkan anggota keluarga, termasuk anak itu sendiri;

6) Cara penggunaannya mudah;

7) Alat peraga yang sudah jadi tidak mudah robek atau rusak;

8) Peserta bisa bertukar alat peraga yang sudah selesai digunakan dengan peserta lainnya.

Pada umumnya, para siswa diikutkan program Taman Bacaan di Sekolah Teologia Kristen Pelangi Kristus oleh para orang tuanya. Para orang tua melihat bahwa memang mereka menunjukkan keterlambatan dalam hal kemampuan membaca jika dibandingkan dengan teman di jenjang kelas dan usia yang sebaya.

Para siswa juga kesulitan mengolah instruksi, baik tertulis maupun lisan. Hal ini menunjukkan bahwa mereka memiliki kesulitan dalam hal mengolah atau memproses bahasa. Ketrampilan mengolah bahasa bisa menjadi masalah dalam kehidupan sehari-hari. Dalam mengerjakan tugas maupun menjaga keselamatan diri sendiri, dibutuhkan kemampuan memahami dan melaksanakan instruksi, baik tertulis maupun lisan.

Selain kesulitan membaca dan mengolah bahasa, para siswa juga ada yang masih sulit menangkap konsep dasar matematika. Konsep dasar dalam hal ini mencakup hal-hal yang paling sederhana, seperti kemampuan menyortir, mengidentifikasi atribut, seperti besar-kecil, atas-bawah, dan sebagainya. Para siswa juga masih kesulitan memahami simbol angka. Hal ini juga menjadi 
faktor yang menjadikan mereka sulit mengikuti pelajaran di sekolah.

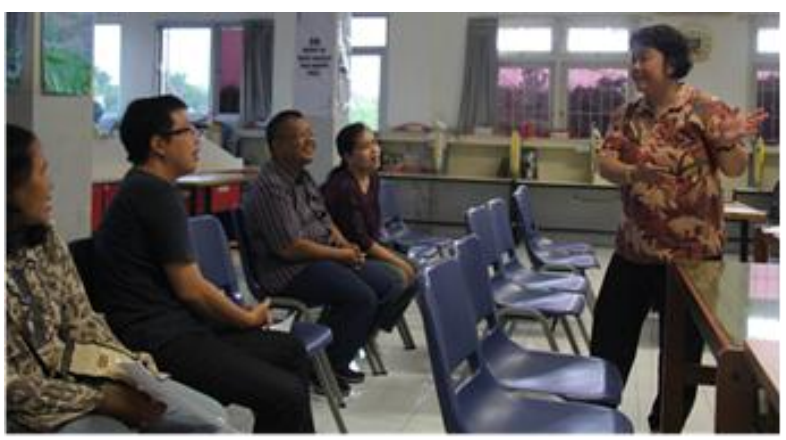

Gambar 1. Kegiatan Pendataan Kebutuhan

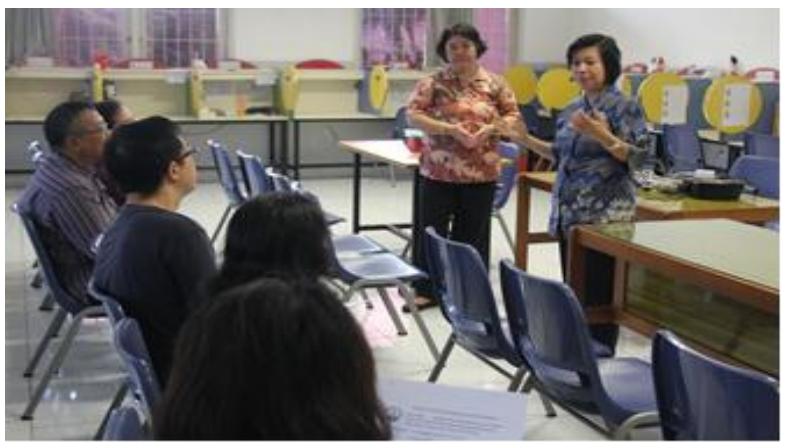

Gambar 2. Percakapan dengan para orangtua murid

Para orang tua dan guru belajar konsep dan teknik pembuatan File Folder Games. Gambar, tulisan atau angka ditempelkan di map lalu dilaminating. Anak-anak mencocokkannya sesuai dengan tujuan yang akan dicapai. Dalam hal ini, diharapkan agar anak bisa melakukannya secara mandiri. Dengan demikian, orang tua dan guru bisa memantau perkembangan pembelajaran anak melalui hasil yang dicapai tanpa intervensi. Bila keterampilan yang ditargetkan telah tercapai, orang tua dan guru bisa merancang capaian pembelajaran berikutnya.

Alat peraga lain yang dibuat adalah materi penunjang penyampaian social story. Anak-anak perlu terus belajar keterampilan bersosialisasi, keamanan (safety), sampai pada kegiatan rutin seharihari. Dalam mendidik mereka, orang tua dan guru harus mencari cara untuk menyampaikannya sesuai dengan mode belajar anak. Anak-anak yang perlu diajari dengan metode visual membutuhkan benda-benda yang bisa membantu mereka belajar, mengingat dan melaksanakannya.

Dalam kegiatan ini, orang tua dan guru bersama-sama menciptakan gambar atau tulisan yang kemudian dirangkai. Rangkaian cerita ini bisa menggunakan ring untuk gantungan kunci, atau hanya sekedar lukisan di kertas buku gambar. Para orang tua dan guru sangat antusias mengembangkan ide mereka. Bahkan, tak sedikit yang meminta tambahan bahan supaya bisa membuatnya lagi di rumah.

Dalam proses membuat alat peraga ini, terjadi diskusi dan studi kasus yang sangat produktif. Para guru dan orang tua mempertimbangkan kemampuan dan kebutuhan anak. Di samping itu, mereka berusaha mengembangkan teknik dan ide yang didapat, lalu melaporkan penggunaannya pada pertemuan berikutnya.

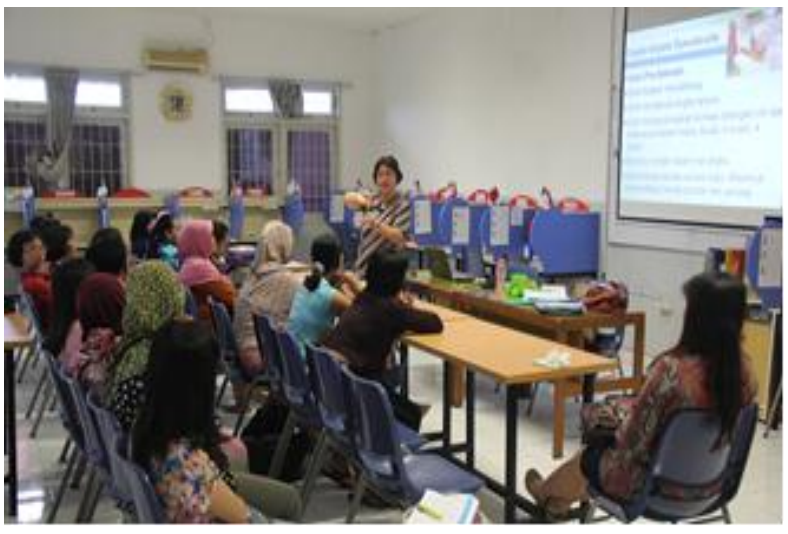

Gambar 3. Orangtua murid sedang serius menyimak penjelasan narasumber

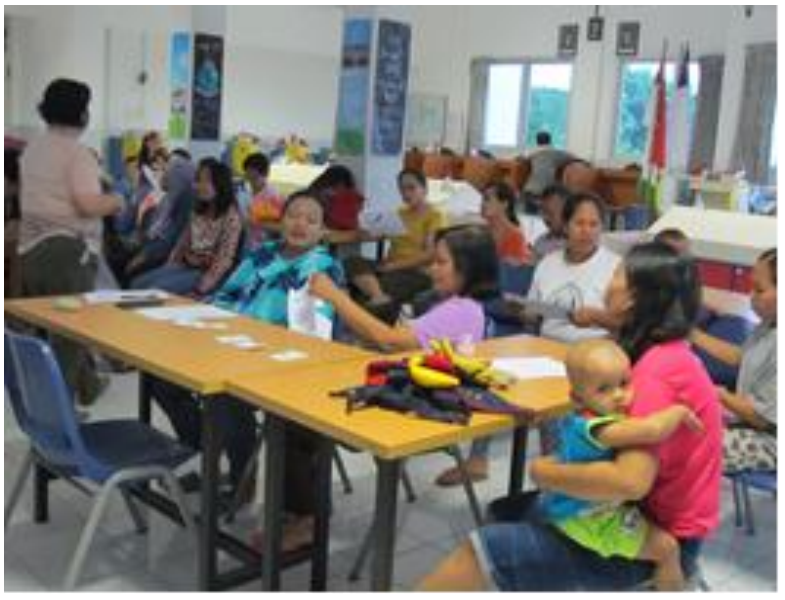

Gambar 4. Diskusi antara narasumber dengan orang tua murid

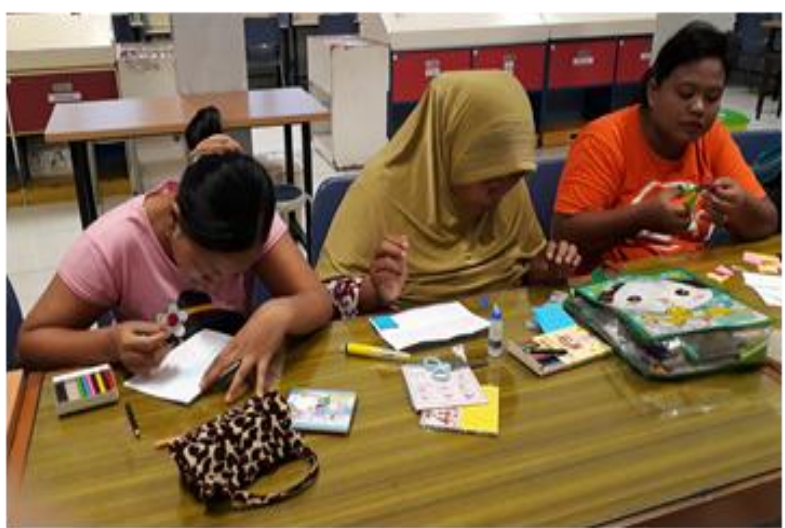

Gambar 5. Orang tua murid mulai membuat alat peraga 


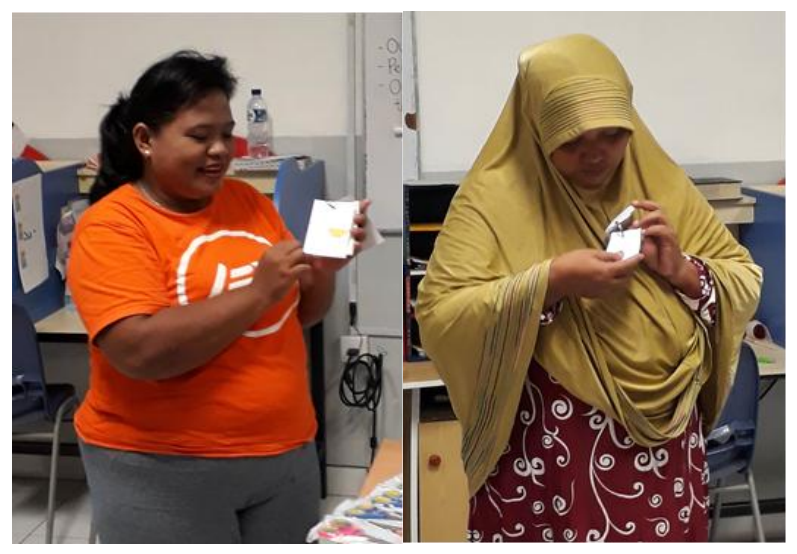

Gambar 6. Para orangtua murid memperagakan penggunaan alat peraga yang telah mereka buat

\section{KESIMPULAN}

Kegiatan pembuatan dan penggunaan alat peraga di Sekolah Teologia Kristen Pelangi Kristus diadakan untuk memetakan tipe kebutuhan khusus para siswa, yang membuat mereka kesulitan mengikuti pelajaran dengan metode mengajar yang konvensional. Kegiatan ini juga membantu para orangtua dan guru mendata intervensi yang dibutuhkan para siswa agar dapat memahami materi pelajaran. Melalui kegiatan ini, para orangtua dan guru juga memberikan intervensi, agar siswa bisa memahami materi dengan lebih mudah.

Berdasarkan masukan dari para peserta program pengabdian pada masyarakat ini, diharapkan program ini berlanjut. Dalam program selanjutnya, diharapkan ada pembahasan yang lebih lengkap dan spesifik. Di samping itu, perlu ada waktu konseling dan studi kasus pada sesi terpisah agar program penyuluhan dapat berlangsung lebih lancar.

Dalam program berikutnya, pengabdian pada masyarakat ini juga bisa digabungkan dengan penelitian ilmiah yang membuahkan laporan yang layak untuk dipublikasikan di jurnal. Hal ini diusulkan Tim Pelaksana mengingat kebutuhan di lokasi ini sifatnya spesifik dan unik. Di samping itu, masih ada anak dan murid yang belum bisa dilayani secara intensif karena keterbatasan waktu.

Program pengabdian pada masyarakat serta penelitian di lokasi yang sama juga bisa melibatkan rekan-rekan dosen dan mahasiswa lain, baik dari program studi PGSD sendiri maupun bekerjasama dengan program studi lainnya. Dengan demikian, para peserta bisa dibekali dengan keterampilan yang lebih kaya lagi.

\section{UCAPAN TERIMA KASIH}

Tuhan berfirman dalam Amsal 22:6, yang berbunyi demikian: "Didiklah orang muda menurut jalan yang patut baginya, maka pada masa tuanya- pun ia tidak akan menyimpang dari pada jalan itu." Salah satu bagian tugas orang tua dan guru adalah mendidik anak, sesuai dengan kelebihan dan kebutuhannya. Kegiatan pengabdian kepada masyarakat ini dilaksanakan untuk membantu para orang tua dan guru memenuhi perintah Tuhan tersebut.

Terima kasih kepada Lembaga Penelitian dan Pengabdian Masyarakat (LPPM) Universitas Kristen Petra, yang telah mengadakan pelatihan, serta memberikan hibah internal. Pembekalan ilmu dan ketrampilan menulis artikel ilmiah melalui program-program LPPM UK Petra juga sangat membantu terselesaikannya artikel ini.

Para pengurus Program Taman Bacaan di Sekolah Teologia Kristen Pelangi Kristus sangat banyak memberikan sumbangsih dan pendampingan selama program pengabdian kepada masyarakat dilaksanakan. Para pendidik dengan antusias mengikuti rangkaian acara. Semangat untuk melayani anak-anak sangatlah terpancar dari kerajinan mereka mengejar ilmu. Kiranya nama Tuhan dimuliakan melalui program ini.

\section{DAFTAR PUSTAKA}

Badan Pusat Statistik. (2015). Penduduk Indonesia: Hasil survei penduduk antar sensus 2015.

Boat, Thomas F. and Wu, Joel T., "Mental Disorders and Disabilities Among Low-Income Children." The national Academies Press, 2015.

Centers for Disease Control and Prevention., U.S. Department of Health \& Human Services https://www.cdc.gov/ncbddd/developmentaldis abilities/features/birthdefects-dd-keyfindings. html

Kamus Besar Bahasa Indonesia. (2016). Disabilitas. Badan Pengembangan dan Pembinaan Bahasa, Kementerian Pendidikan dan Kebudayaan Republik Indonesia. Retrieved from https://kbbi. kemdikbud.go.id/entri/disabilitas

Kaldenberg, E. et al. 2014. Reading Instruction in Science for Students with Learning Disabilities: A Meta-Analysis. Learning Disability Quarterly, Hammill Institute on Disabilities: 1-14.

Kementerian Kesehatan Republik Indonesia. (2014). Situasi penyandang disabilitas. Buletin Jendela Data \& Informasi Kesehatan, Semester 2, 2014.

National Dissemination Center for Children with Disabilities. 2004. Learning Disabilities. Disability Fact Sheet, no.7 (January). http://www. nichcy.org/pubs/factshe/fs7.pdf.

Pusat Data dan Informasi Kementerian Kesehatan Republik Indonesia. (2014, December 3). Penyandang disabilitas pada anak. 